\title{
The OTA on the EPA
}

\section{WillLepkowski looks at the US Environmental Protection Agency, the subject of a recent report.}

WhEN the Environmental Protection Agency was formed in late 1970, one of the justifications for its creation was that a single agency could take better responsibility for restoring environmental quality than a group of separate fiefdoms. EPA, the argument went, would view the environment as a single, interrelated whole through an administrative structure that was itself correspondingly integrated. Environmentally conscious America heaved a sigh of assurance that at last the quality of life and the preservation of Spaceship Earth were given the policy enthronement they merited.

While the human cell may be the perfect blending of structure and function, EPA decidedly is not. It has faced many reorganisations of its research and development branches, internal controversies, budgetary disappointments and manpower freezes; it has suffered from conflicting Congressional mandates, court setbacks to its enforcement decisions, political shoving matches, and has had its programmes skewered by new energy policies. Little wonder, then, that EPA continues to find the exercise of leadership elusive.

In the past, EPA was buffeted by policy fashion as well as by legitimate currents of change. Until the late $1960 \mathrm{~s}$, for example, environmental control was seen as a problem of public health protection, and was thus housed in the Department of Health, Education, and Welfare (HEW). Gradually, however, the emphasis began to shift from defining health problems as guidelines for environmental control to achieving technological solutions. The health problem obviously remained, but Congress decided that HEW was no place for the development of technology or the understanding of complex ecological systems, and EPA was created.

It can be fairly stated that EPA never could boast of a consistent research policy. Hopes ran high during its first two years when systems analysts descended upon headquarters. But systems mythology could only but clash with traditions rising out of wet chemistry and sanitary engineering. Goals seldom squared with realities, especially in environmental regulation where research strategies were usually dictated by crises emerging each week. To be an EPA researcher was to be unhappy. Besides being bureaucratically overarching but arthritic, the agency was acutely politicised by the Nixon Administration.

\section{Five year plan}

Out of the wreckage-but in many cases reflective of it-rises a five-year research and development (R\&D) plan that Congress's Office of Technology Assessment (OTA) has just finished analysing for the committee on science and technology. OTA has little good to say of it; indeed, during the assessment process, EPA scrapped the word "plan" and substituted "outlook". It says in essence that EPA's plan is not a plan and as such is no guideline for helping direct long term policies for the country.

"Foremost among the shortcomings in the R\&D plan," OTA's report says, "is EPA's failure to indicate a commitment to long range research and, as a corollary, an excessive focus on short term R\&D issues related directly to the enforcement and/or achievement of EPA's current regulations. Accordingly," it goes on,

the Plan emphasises the development and demonstration of control technologies. In many cases, however, the larger problems involve social, economic and institutional patterns which not only impede technical solutions but which require nontechnical approaches. To develop effective overall environmental management strategies will require more systematic and sustained socioeconomic research efforts than those specified in the Plan. An added R\&D emphasis on long range environmental concerns and a more responsive role to its line of responsibility as coordinator of Federal environmental R\&D would do much to enhance EPA's effectiveness and credibility.

The US is obviously already environmentally conscious. Whether it is environmentally cleaner is another question. The recent outbreak of the so-called "legionaires disease" in Philadelphia appears to be caused by a toxic metal whose origins and precise identity are still under investigation. Evidence points to nickel carbonyl from microcapsulised paper that requires no carbon paper for the typing of copies. Whatever the cause, the point is that toxic chemicals are everywhere in the environment, and EPA must always play a "catch-up" role.

But anticipation is the name of the environmental game in its ideal, and EPA's record as an anticipatory research agency is a sorry one. Yet, anticipatory research is a sorry subject given the complexities of industrialisation and ecosystems. The obvious alter- native is to require industry to stop producing anything toxic to begin with. EPA would administer the pending toxic substances control Act which would do just that, but Congress seems hesitant to pass a law so distasteful to industry. It has been "pending" for almost a decade. If passed, however, EPA would become in theory much like the Food and Drug Administration with its main regulatory goal being prevention rather than reaction. Wondering what to react to has always produced bureaucratic psychosis.

EPA's problems over the last few years have been money, manpower and morale. The EPA report doesn't appraise the morale problem because the charge was only to assess the Plan itself. But the panels which gathered to make the critique were composed of individuals familiar with the agency's internal problems and the moribund psychology of the agency. That issue wasn't discussed, despite its centrality. The research arm of the agency is plainly dejected. Individual scientists know what needs to be done to begin anticipating the environmental future, but they know too that doing it would require ten times the present research budget of $\$ 250$ million.

\section{Questionable help}

Thinking about environmental futures is often a pathway to dejection, especially considering the fact that industrialisation of the less developed nations entails no pollution control to speak of. And oceanographers have long since despaired to any effective pollution control policy for the oceans.

How much of a help OTA's critique of the plan will be is questionable. It says it isn't a plan. It says the main issues are socioeconomic and EPA hardly knows how to ask the right questions in such a fuzzy area of parascience. It says EPA knows next to nothing about the long term effects of pollution. It says EPA has a weak health research capability. It is a litany of deficiencies. The sorry fact is that the same criticisms were made of environmental research 15 years ago.

The findings have long since been seen and mulled over by the House science and technology committee. But the practical and philosophical deficiencies pointed out in the OTA report transcend solution without profound changes in consciousness among those who make budgets and plan strategies. And, of course, the entire milieu within EPA would change once Congress passes the toxic substances bill. But that would mean further growth in the regulatory bureaucracy and, of course, larger costs of doing business. The present Administration opposes both. 